Winter 2003

\title{
Globalization and Governance: The Prospects for Democracy
}

Sir David Williams David Q. C.

University of Cambridge

Follow this and additional works at: https://www.repository.law.indiana.edu/ijgls

Part of the International Law Commons

\section{Recommended Citation}

Williams, Sir David David Q. C. (2003) "Globalization and Governance: The Prospects for Democracy," Indiana Journal of Global Legal Studies: Vol. 10 : Iss. 1 , Article 7.

Available at: https://www.repository.law.indiana.edu/ijgls/vol10/iss1/7

This Symposium is brought to you for free and open access by the Law School Journals at Digital Repository @ Maurer Law. It has been accepted for inclusion in Indiana Journal of Global Legal Studies by an authorized editor of Digital Repository @ Maurer Law. For more information, please contact rvaughan@indiana.edu.

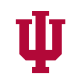

JEROME HALL LAW LIBRARY

INDIANA UNIVERSITY

Maurer School of Law
Blooming ton 


\title{
Globalization and Governance: The Prospects for Democracy
}

\author{
Sir DaVid Williams*
}

\section{INTRODUCTION}

The contours of public law are changing rapidly, and judges, practitioners, and academic writers are anxiously seeking a guide to the new frontiers. ${ }^{1}$ Reference has been made by some American observers to the "profound changes brought about by deregulation, commercialization, corporatization, public sector downsizing, privatization and globalization."2 At the same time, the courts in many jurisdictions are revising the language as well as the substance of the changing law, often by reference to developments in other countries, and there is renewed concern about the prospects for democracy in a climate of globalization, with issues of democratic governance unsurprisingly achieving prominence in public international law as well as in national law. ${ }^{3}$ Democracy "used to be a word that international commentators preferred to avoid," and it is a term that has often invited skepticism or embarrassment in domestic law.

In writing on "The Democratic Character of Judicial Review" Eugene Rostow commented that democracy "is a slippery term," and it is doubtless wise to avoid a firm definition. The existence of a free, democratic system of government creates, in the words of Ivor Jennings, "an atmosphere of freedom which is more easily felt than analyzed," and it is possible to speak of

* Emeritus Vice-Chancellor, University of Cambridge and Emeritus Rouse Ball Professor of English Law, University of Cambridge.

1. See generally THE PROVINCE OF ADMINISTRATIVE LAW (Michael Taggart ed., 1997) (a collection of papers that reflect a host of angles on and perceptions about administrative law, constitutional law, public law and many aspects of private law).

2. Michael Taggart, The Province of Administrative Law Determined?, in THE PROVINCE OF ADMINISTRATIVE LAW supra note 1, at 1, 2; see also Alfred C. Aman, Jr., Administrative Law for a New Century, in THE PROVINCE OF ADMNISTRATIVE LAW, supra note 1, at 90-117.

3. See generally DEMOCRATIC GOVERNANCE AND INTERNATIONAL LAW (Gregory H. Fox \& Brad R. Roth eds., 2000).

4. Susan Marks, International Law. Democracy, and the End of History, in DEMOCRATIC GOVERNANCE AND INTERNATIONAL LAW, id. at 532.

5. Eugene Rostow, The Democratic Character of Judicial Review, 66 HARV. L. REV. 193, 199 (1952).

6. IVOR JENNINGS, THE LAW AND THE CONSTITUTION 61 (5th ed. 1954). 
parliamentary institutions, of second chambers, of free elections, of fair elections, of judicial review (in one form or another), of the protection of human rights, of transparency, and of freedom of information as the attributes of democracy which would command attention. At the same time, the emphasis on any of these attributes could vary significantly, and there can be major differences of view as to the precise machinery necessary to achieve them. Amid the many constitutional changes undertaken or mooted in the United Kingdom since 1997, there is ample evidence of the foot dragging that occurs when the ground seems much more shaky than originally contemplated; it would be misleading to ignore such evidence in the context of trends towards globalization.

Despite various positive achievements, ranging from incorporation of the European Convention on Human Rights to varying schemes of devolution under legislation of 1998, there has been disappointment in several areas. Initial plans for greater open government were welcomed, but later legislative proposals were more restrictive; implementation of the Freedom of Information Act (FOIA) of 2000 has, even so, been delayed. At the outset of negotiations concerning the FOIA, there was a gesture towards globalization in the acknowledgment that the United Kingdom could learn from the experience of "mature fellow democracies" such as Sweden, the United States, Canada, Australia, New Zealand, and the Netherlands, ${ }^{7}$ and the FOIA of 2000 still reflected considerable overseas influence. Changes in the voting system for the Westminister Parliament were confidently expected after a measure of proportional representation was introduced for the devolved assemblies in Edinburgh, Belfast, and Cardiff, the introduction of proportional representation in elections to the European Parliament, and publication, in 1998, of the Report of the Independent Commission on the Voting System. The Commission had been charged with recommending for Westminister the best alternative "system or combination of systems" to the existing "First Past the Post" (FPTP) system of election, with the expectation that the matter would be put to the British electorate in a referendum. One of the criteria emphasized by the Commission was that of fairness to voters, and the electoral systems of other countriesincluding the Republic of Ireland, Germany, Israel, Italy, France, New Zealand, Australia, India-were described. It was accepted that the United Kingdom shares FPTP with Canada and the United States, but no referendum has yet

7. YOUR RIGHT TO KNOW: THE GOVERNMENT'S PROPOSALS FOR A FREEDOM OF INFORMATION ACT, 1997, Cm. 3818, १1 1.3. 
been held or planned on whether we should retain that system. The Commission did make this comment:

The United States is of course the most powerful democracy in the world, with an impressive record of world leadership for nearly the past sixty years. On the other hand it is a presidential and not a parliamentary system in the British sense (which may be good or bad but weakens the comparison), its level of participation in elections, at barely $50 \%$ for Presidential elections and only $37 \%$ in the last midterm Congressional elections, is appallingly low, and some would say that its system of government has not recently been a great advertisement for democratic maturity. ${ }^{8}$

What, then, of the second chamber of Parliament at Westminster-the unelected House of Lords? After the House of Lords Act 1999, which severely curtailed the hereditary element, there was a Report of the Royal Commission in $2000^{9}$ that produced 132 recommendations and led to expectations of widespread reform of the second chamber. Delay followed, and it was only in November 2001 that a White Paper appeared, ${ }^{10}$ opening with the Prime Minister's words that a "credible and effective second chamber is vital to the health of Britain's democracy." This fresh contribution by the Government spoke of removing the hereditary element completely, of reemphasizing the constitutional preeminence of the House of Commons, of retaining a legislative, deliberative, and scrutinizing role for the House of Lords, of modestly extending the powers of the second chamber in secondary legislation, and of organizing its composition to allow for a majority of nominated members and a minority elected element. Conscious once again of comparative guides, the Government stressed that directly elected second chambers are not common elsewhere: the "idea that the directly elected US Senate is the norm against which others should be judged is wrong. It is a component of the interlocking federal arrangements within the USA."

\footnotetext{
8. REPORT OF THE INDEPENDENT COMMISSION ON THE VOTING SYSTEM, 1998, Cm. 4090-1, $\{77$.

9. See REPORT OF THE ROYAL COMMISSION ON THE HOUSE OF LORDS, A HOUSE FOR THE FUTURE, 2000, Cm. 4534 .

10. THE HOUSE OF LORDS, COMPLETING THE REFORM, 2001, Cm. 5291.

11. Id., $\$ 37$.
} 
composition were not widely welcomed and there was widespread support for a larger elected membership. New legislation is unlikely for some time yet.

As the courts of law face the challenges of globalization, much remains to be done in improving democratic institutions and democratic accountability. The justice system is itself under scrutiny, and once again external models are important. In March 2001, for instance, there appeared a Report on Tribunals ${ }^{12}$ that examined a host of administrative tribunals or agencies other than ordinary courts of law, with the emphasis on efficiency, faimess, coherence, public understanding, and compatibility with the requirements of the European Convention on Human Rights as to independence and impartiality. The jurisdiction of the seventy or so categories of tribunal discussed extended to such areas as taxation, social security, mental health, immigration, employment, school admissions, criminal injuries compensation, and pensions. Globalization is reflected in the work of the Immigration Appellate Authorities, which hear appeals from refusal of asylum or of permanent residence in the United Kingdom, and it is also reflected in parts of the Report concerned with Information Technology, devolution within the United Kingdom, and the system of administrative justice created at federal level in Australia through innovative and important statutes of the 1970s. ${ }^{13}$ The work of the Council on Tribunals, which currently supervises over eighty tribunals and other agencies, including the Civil Aviation Authority, the Director-General of Fair Trading, the National Lottery Commission, and the Occupational Pensions Regulatory Authority, was also considered and endorsed. In its latest Annual Report, the Council spoke of the importance of overseas contacts, not least "to gain insight into how different legal and administrative systems tackle the problems with which we are concerned," $" 14$ and referred to the visit of a Russian delegation and to a major conference on administrative justice, hosted in Quebec by the Council of Canadian Administrative Tribunals.

Also issued in 2001 was the Review of the Criminal Courts of England and Wales, conducted by Lord Justice Auld. Full account was taken of experience in Europe generally and in North America, and public responses and

12. Sir ANDREw Leggatt, Tribunals for USERS: ONe System, ONE SERVICE: RePORT OF THE REVIEW OF TRIBUNALS (2001).

13. See ADMINISTRATIVE REVIEW COUNCIL, TWENTY-FIFTH ANNUAL REPORT: 2000-2001: SUbMisSiON TO THE LEGGATT REVIEW, 27-41 (Aug. 2001).

14. COUNCIL OF TRIBUNals, ANNUAL RePORT 2000/2001, [2001] H.C. 343, SE/2001/275 (Nov. 20, 2001), available at http://www.council-on-tribunals.gov.uk/home.htm; see also BERNARD SCHWARTZ \& H.W.R. WADE, LEGAL CONTROL OF GOVERNMENT: ADMINISTRATIVE LAW IN BRITAIN AND THE UNITED STATES, 107-84 (1972) (comparing tribunals and agencies in the United Kingdom and the United States). 
perceptions were-as in the Leggatt Report-carefully examined. Historical misconceptions about jury trial were also exposed: there is no "right" to jury trial, neither under Magna Carta, nor as a "constitutional entitlement" as in the United States and Canada, nor as a result of incorporation of the European Convention on Human Rights. ${ }^{15}$ Lord Justice Auld rejected any democratic element in jury service, and he saw no justification for moving to the U.S. system of jury challenges. ${ }^{16}$ As for "perverse verdicts," when juries allegedly disapprove of the law or of particular prosecutions in apparent "dispensing" verdicts of "not guilty," they are seen as a "blatant affront to the legal process" and to efforts to combat crime. ${ }^{17}$ Much of the general discussion on these and other matters, in a lengthy and detailed Report, could cross frontiers and add to the impact of globalization. Both the Leggatt and the Auld Reports remind us of the volatility of legal systems as they adapt to new and shared challenges and problems.

\section{THE ROLE OF THE COURTS}

The cross-frontier fertilization of principles of public law has been greater in its impact on the United Kingdom than on the United States. The external jurisdiction of the Judicial Committee of the Privy Council has had a vital influence in some areas, often offering British judges an opportunity to correct or modify unsatisfactory domestic developments. In Nakkuda Ali v. Jayaratne,$^{18}$ the Judicial Committee took a restrictive view of the application of natural justice or procedural due process, but effectively undermined a leading and controversial wartime case ${ }^{19}$ on the limits of discretionary power. Moreover, the resurgence of natural justice in later years was underpinned by several cases decided by the Judicial Committee. ${ }^{20}$ In a different area of the law altogether-that concerned with the so-called offence of contempt of court by "scandalizing the court"- the Judicial Committee had, many years earlier,

15. LORD JUSTICE AULD, REPORT OF THE REVIEW OF THE CRIMINAL COURTS OF ENGLAND AND WALES, [2001] H.C. 343, 138, available at http://www.criminal-courts-review.org.uk.

16. Id. at 163.

17. Id. at 175 .

18. [1951] App. Cas. 66 (P.C.) (appeal taken from Sup. Ct. Ceylon).

19. Liversidge v.Anderson, [1942] App. Cas. 206 (appeal taken from Ct. App.).

20. See, e.g., Kanda v. Government of Malaya, [1962] App. Cas. 322 (appeal taken from Ct. App. Malaya); Annamunthodo v. Oilfield Workers Trade Union, [1961] App. Cas. 945 (P.C.) (appeal taken from Fed. Sup. Ct. West Indies); Durayappah v. Fernando, [1967] 2 App. Cas. 337 (P.C.) (appeal taken from Sup. Ct. Ceylon). An important recent constitutional case from Barbados is Hinds v. Barbados (Attomey Gen.), [2002] 1 App. Cas. 854 (P.C. 2001) (appeal taken from Ct. App. Barbados). 
injected a sobering influence in the name of free speech. This was particularly so in a case where the Acting Chief Justice of St. Vincent had been inter alia described as "narrow, bigoted, vain, vindictive, and unscrupulous."21 This quaint branch of the law of contempt of court was largely sidelined when Lord Atkin stated in another and more recent ruling of the Judicial Committee that justice "is not a cloistered virtue: she must be allowed to suffer the scrutiny and respectful, even if outspoken, comments of ordinary men."22

Within the United Kingdom the Judicial Committee has recently acquired power to adjudicate devolution issues arising from Edinburgh, Belfast, or Cardiff, not least from the launching pad of human rights. In a decision in late 2000, for instance, the Judicial Committee reversed a ruling by the High Court of Judiciary in Scotland that the defendant in a drunk-driving case had been denied a fair trial under Article 6 of the European Convention on Human Rights. $^{23}$

The impact of membership in the European Union and of incorporation of the European Convention on Human Rights has been recognized by all courts in the United Kingdom. Close attention now has to be paid to the jurisprudence of the European Court of Justice in Luxembourg and the European Court of Human Rights in Strasbourg, and many features, and some of the vocabulary, of public law have inevitably changed. In a case before the House of Lords, a chief constable's exercise of discretion in the area of public order was upheld against a familiar administrative law challenge and against the claim that it was disproportionate, and hence invalid, under a provision of the Treaty of Rome. ${ }^{24}$ The two tests - of "Wednesbury reasonableness and proportionality"-were seen by Lord Slynn as much the same in practice; and Lord Cooke of Thorndon agreed with the proposition "that on the particular facts of this case, the European concept of proportionality and margin of appreciation produce the

21. McLeod v. St. Aubyn, [1899] A.C. 549, 555 (P.C.) (appeal taken from Sup. Ct. of St. Vincent). The offending article forecast that the Acting Chief Justice would "prostitute one of the most sacred secular positions merely to gratify his venom and his spleen." Id. at 553; see also In the Matter of Special Reference from the Bahama Islands, [1893] AC 138 (P.C.) (Special Reference case from the Sect. of State of the Colonies).

22. Ambard v. Attorney General for Trin. \& Tobago, [1936] A.C. 322, 335 (P.C.) (appeal taken from the Sup. Ct. of Trin. \& Tobago); see also, Regina v. Metropolitan Police Commissioner, [1968] 2 Q.B. 150 (Eng. C.A.).

23. Brown v. Stott, [2001] 2 All E.R. 97 (P.C.) (appeal taken from the High Ct. Scot.).

24. Regina v. Chief Constable of Sussex, Ex parte International Trader's Ferry Ltd., [1999] 2 A.C. 418 (H.L.) (appeal taken from Ct. App.). The familiar formula for challenging abuse of discretion is derived from the Court of Appeal's decision in Associated Provincial Picture House Ltd. v. Wednesbury Corporation, [1948] I K.B. 223 (Eng. C.A.) and is often referred to as "Wednesbury unreasonableness." 
same result as . . the Wednesbury principles. Indeed, in many cases, that is likely to be so." The chief constable, he added, "struck a fair and reasonable balance which survives scrutiny under purely domestic law and European originating domestic law alike.,"25

The "inevitable convergence of British and European law"26 in many phases of public law is further illustrated in $R v$. North and East Devon Health Authority, ex $p$ Coughlan (Secretary of State for Health intervening) ${ }^{27}$ where, in the highly sensitive area of non-residential provision for the chronically sick and disabled, the Lord Chief Justice-speaking for the Court of Appeal-held on the facts that the applicant for judicial review had a legitimate expectation of a substantive benefit and that to frustrate that expectation would be so unfair as to amount to an abuse of power. The Lord Chief Justice, fully aware of legal developments as to standards of faimess in the law of the European Union, ${ }^{28}$ declined to allow the challenge to the exercise of discretion to be assessed on Wednesbury grounds alone. ${ }^{29}$ In another recent case, the House of Lords upheld the legitimacy of the Minister's role in determining important planning matters despite claims that there had been a violation of the entitlement to have civil rights and obligations determined by an independent and impartial tribunal under Article 6(1) of the European Convention. ${ }^{30}$ In overturning the ruling of the Divisional Court below, the House of Lords was clearly aware of the democratic implications of the dispute. Echoing words used by Lord Bingham in the Scottish "devolution issue" case in the Privy Council, ${ }^{31}$ Lord Hoffmann spoke of democracy and the law and saw no conflict between human rights and the democratic principle. He went on to emphasize that the European Court of Human Rights, while often following a "tortuous path in its jurisprudence, has never attempted to undermine the principle that policy decisions within the

25. Chief Constable of Sussex, [1999] 2 A.C. at 439, $452,454$.

26. H.W.R. WADE \& C.F. FORSYTH, ADMINISTRATIVE LAW 373 (8th ed. 2000).

27. [2001] Q.B. 213 (C.A.); see Mark Elliott, Legitimate Expectations: The Substantive Dimension, 59 CAMBridge L.J. 421 (2000); Regina ex rel. Bibi v. Newham London Borough Council, [2002] W.L.R. 237 (C.A.).

28. N. \& E. Devon Health Auth., [2001] Q.B. at 243.

29. Id. at 251 .

30. Regina ex rel. Alconbury Developments Ltd. v. Sec'y of State for the Env't, Transp., and the Regions, [2001] 2 W.L.R 1389 (H.L.) (appeal taken from Div. Ct.); see also Paul Craig, The Courts, the Human Rights Act and Judicial Review 117 L.Q. REV. 589 (2001); Adan v. Newham London Borough Council, [2002] 1 All E.R. 931 (C.A.).

31. See Brown, [2001] 2 All E.R. at 114 (stating that "judicial recognition and assertion of human rights defined in the Convention is not a substitute for the processes of democratic government but a complement to them"). 
limits imposed by the principles of judicial review are a matter for democratically accountable institutions and not for the courts. ${ }^{.32}$ Clearly, the British courts are having to come to terms with new pressures and demands in public law, and their judges have been obliged to look at the democratic implications of shifting emphases in judicial review in the light of European influence. The European Union has its own institutional framework, based on Brussels in particular, but also on the European Parliament and the European Court of Justice; there is a growing volume of European law generated through the various institutions, much of it regulatory in tone; and issues of democracy become more and more complicated. There are-inevitably, given the complexity involved - considerable concerns about democratic accountability. It is no longer a question of accountability of the executive to one Parliament at Westminister, with the elected House of Commons to the fore. It is now a question of additional and appropriate accountability downwards, through the devolution schemes, and outwards, through the European institutions. In particular, there are problems of accountability-to democratic institutions and to the courts of law-in times of crisis, especially as they bring into focus the problems of judicial restraint in the face of global problems.

\section{GLOBALIZATION AND CRISIS}

Several American writers have explored the problems of democracy in times of crisis. Clinton Rossiter wrote in 1948 about "constitutional dictatorship" in the responses in France, Germany, the United Kingdom, and the United States, especially, but not exclusively, in time of war. ${ }^{33}$ He stressed the contrast between the severely weakened British Parliament during the First World War and the stronger democratic role it exercised in the Second World War. ${ }^{34}$ According to Rossiter, the Bill of Rights, federalism, and the separation of powers were the "three main constitutional barriers to the easy establishment of emerging dictatorship in the United States. ${ }^{135}$ Rossiter also took full account of judicial decisions such as Liversidge $v$. Anderson $^{36}$ in the United Kingdom

32. Ex rel. Alconbury Dev. Ltd., [2001] 2 W.L.R. at 1411-13.

33. Clinton Rossiter, CONSTITUtional Dictatorship: Crisis GOVERNMENT IN MOdeRN DEMOCRACIES (Harcourt, Bruce \& World, Inc. 1963) (1948).

34. Id. at $162,195$.

35. Id. at 212 .

36. [1942] A.C. 206; see also ROSSITER, supra note 33, at 198 (discussing Liversidge in the context of the detention of aliens in the Second World). See generally A.W. BRIAN SIMPSON, IN THE HIGHEST DEGREE OdIOUS: DetentIon WITHOUT TRIAL IN WARTIME BRITAN (1992). 
and the Japanese-American evacuation cases in the United States. ${ }^{37}$ Other writers who have discussed the constitutional strain in times of crisis include Edward S. Corwin, ${ }^{38}$ Harold Laski, ${ }^{39}$ and Harry Howe Ransom. ${ }^{40}$ In the epilogue to Can American Democracy Survive the Cold War?, written in 1963, Ransom stated that surely "the future offers an intensification of the burdens of democratic government, with foreign and military policy always as the Achilles heel of democracy. ${ }^{, 41}$

Any major crisis-military, diplomatic, economic, or environmental-is certain to have effects and implications beyond the borders of one country or one geographical region, and these effects and implications are speedily recognized in a world of rapid communications and high technology. Moreover, the resolution of many cases demands some form of international cooperation. A provisional settlement of the thirty year troubles in Northern Ireland was achieved in the Good Friday Agreement of $1998^{42}$ only with the active involvement of the Irish and American governments, as well as the government of the United Kingdom. Individuals from outside the United Kingdom have contributed significantly in the peace process itself and in consequential matters, such as the decommissioning of arms, and the institutional support for the future of the peace process requires formal links between the Republic of Ireland and the United Kingdom. Much of the activity of several groups operating in Northern Ireland could properly be described as terrorism, a term which is essentially defined in the Terrorism Act of 2000 in the United Kingdom as "the use, or threat, of action which is violent, damaging or disrupting and is intended to influence the government or intimidate the

37. ROSSITER, supra note 33, at 280. The main decision was Korematsu v. United States, 323 U.S. 214 (1944). See generally EUGENE V. ROSTOW, THE SOVEREIGN PREROGATIVE: THE SUPREME COURT AND THE QUEST FOR LAW, ch. 7 (1962).

38. EDWARD S. CORWIN, TOTAL WAR AND THE CONSTITUTION (1947). E. Blythe Stason said that Corwin's lectures were concerned with the events immediately prior to and during World War II, "resulting in the shift in constitutional dominance over affairs of the nation from the legislative and judicial supremacy of bygone years to the ascendancy of the executive branch of government." E. Blythe Stason, Introduction to TOTAL WAR AND THE CONSTITUTION, id. at vii.

39. Harold J. Laski, Government in War Time, in WHERE STANDS DEMOCRACY? A COLLECTION OF ESSAYS BY MEMBERS OF THE FABIAN SOCIETY 1 (1940) (Laski opens his contribution with an essay entitled Democracy and War).

40. HaRRY Howe RaNSOM, CAN AMERICAN DEMOCRACY SURVIVE THE COLD WAR (1963).

41. Id. at 252 .

42. THE BELFAST AGREEMENT: AN AGREEMENT REACHED AT THE MULTI-PARTY TALKS ON NORTHERN IRELAND, 1998, Cm. 3883. 
public and is for the purpose of advancing a political, religious or ideological cause. ${ }^{, 43}$

Terrorism, as we are reminded by the Defence Committee of the House of Commons, "is not a recent phenomenon." The first reference to terrorism cited in the Oxford English Dictionary appeared in 1798, and during the nineteenth century "many of the forms of traditional terrorism, with which we were familiar in the twentieth century, were developed. Between 1880 and 1887 terrorists from Irish-American organizations based in the United States carried out a series of bombings in London and also attacked Glasgow and Liverpool." September 11 th, the Defence Committee added, several writers had speculated about "the growth of a new form of terrorism which brought with it a new level of threat." ${ }^{.45}$ The response since September 11th-judicial, as well as legislative and executive and through the United Nations and other international organizations-shows a new globalization of approach, with obvious implications for democratic institutions and standards.

The courts in the United Kingdom have never been at ease in matters of national security, whether in times of war or peace. In the context of the criminal law relating to official secrets, the House of Lords has recently confirmed the limits of any defense based on the public interest $;{ }^{46}$ and in administrative law the courts "are exceedingly reluctant to challenge the executive where national security is pleaded by the government in judicial proceedings. ${ }^{277}$ The concept of national security itself has been transformed since September 11 th, as two decisions of the House of Lords in the contexts of deportation and extradition clearly demonstrate.

The case of Secretary of State for the Home Department v. Rehman ${ }^{48}$ was decided on October 11,2001. The appellant, a Pakistani national, allegedly belonged to an Islamic terrorist organization abroad, but it was deemed unlikely that he and his followers would carry out any acts of violence against the United Kingdom. Nonetheless, a deportation order was entered on grounds of national security, and the House of Lords ruled, in the words of Lord Slynn,

\footnotetext{
43. SECOND REPORT OF THE DEFENCE COMMITTEE: THE THREAT FROM TERRORISM, 2001, H.C. 348-1 II

44. Id., ๆ 15 .

45. Id.

46. Regina v. Shayler, [2002] 2 All E.R. 477 (H.L.) (appeal taken from Ct. App.).

47. HILAIRE BARNETT, CONSTITUTIONAL AND ADMINISTRATIVE LAW 971 (3d ed. 2000).

48. [2002] l All E.R. 122 (H.L.) (appeal taken from Ct. App.).
} 5. 
"that, in contemporary world conditions, actions against a foreign state may be capable indirectly of affecting the security of the United Kingdom." Relevant factors to be taken into account by the Home Secretary included the "sophistication of means available, the speed of movement of persons and goods, [and] the speed of modern communications." accepted the Secretary of State's submission "that the reciprocal co-operation between the United Kingdom and other states in combating international terrorism is capable of promoting the United Kingdom's national security." 50 More generally, the House of Lords emphasized the special competence of the Secretary of State in matters of national security. Lord Steyn, for instance, said that it is well established in the case law "that issues of national security do not fall beyond the competence of the courts," but that it was "self-evidently right that national courts must give great weight to the views of the executive on matters of national security." powers and claimed that under "the constitution of the United Kingdom," matters of national security are not for judicial decision. Indicating that he had written his speech some three months before 11 September, he said that the events in New York and Washington underlined the need to respect executive assessments of national security. ${ }^{52}$

The case of In re Al-Fawwaz ${ }^{53}$ was decided on 17 December, 2001. The government of the United States, which sought extradition of persons alleged to be party to a terrorist conspiracy, challenged an interpretation by the Divisional Court of the Queen's Bench Division of statutory provisions on extradition. The alleged conspiracy was between Osama bin Laden and others between 1993 and 1998, and the point at issue was "whether the extradition crime ruled on must be alleged to have been committed in the United States or whether it is sufficient that it is within the United States' jurisdiction in the sense that it is triable in the United States. ${ }^{\prime 54}$ The statutory background and relevant case law presented difficulties, but Lord Slynn was concerned that the narrower view "would make it impossible to extradite for some of the most serious crimes now committed globally or at any rate across frontiers. Drug smuggling, money laundering, the abduction of children, acts of terrorism, would to a considerable

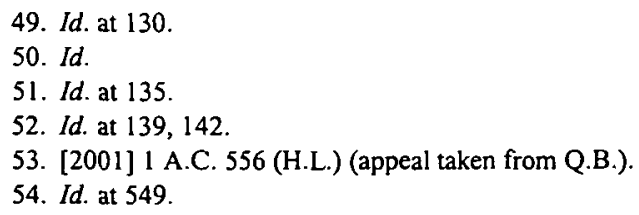


extent be excluded from the extradition process. ${ }^{1,55}$ Lord Hutton spoke likewise of "the modern world of international terrorism and crimes," spoke of "today's global village where national borders are no impediment to international terrorists and other criminals." ${ }^{.57}$ Lord Scott, however, emphasized that the charges against the appellants in the conjoined appeal were laid before the United States District Court for the Southern District of New York and that he "imagined" that, if extradited, the appellants would be tried before that court, or some other federal court, and not before a military tribunal. ${ }^{58}$

These two important decisions show how both control of the exercise of executive judgment in deportation proceedings and the process of statutory interpretation in extradition can be crucially affected by new global challenges or threats. The judges were acutely aware of the wider constitutional issues. Lord Hoffmann, in the Rehman case, noted that the executive's view on natural security demanded respect by the courts because its decisions, "with serious political results for the community, require a legitimacy which can be conferred only by entrusting them to persons responsible to the community through the democratic process. If the people are to accept the consequences of such decisions, they must be made by persons whom the people have elected and whom they can remove." ${ }^{, 59}$ Indeed, an immediate legislative response to the new global challenges or threats was seen in the Anti-Terrorism, Crime and Security Bill. This bill was introduced in the House of Commons on 12 November 12, 2001, and was speedily enacted, albeit with some concessions and the withdrawal of provisions designed to extend offenses based on incitement of racial hatred to cover religious hatred as well. The Act is intended "to strengthen legislation in a number of areas to ensure that the Government, in the light of the new situation arising from the September 11 terrorist attacks on New York and Washington, have the necessary powers to counter the increased threat to the UK." ${ }^{, 60}$ It includes provisions on terrorist property, the power to freeze assets, disclosure of information, immigration and asylum, weapons of destruction (chemical, nuclear and biological weapons), control of pathogens and toxins, a reinforced regulatory regime for nuclear security, aviation security requirements, police powers, retention of

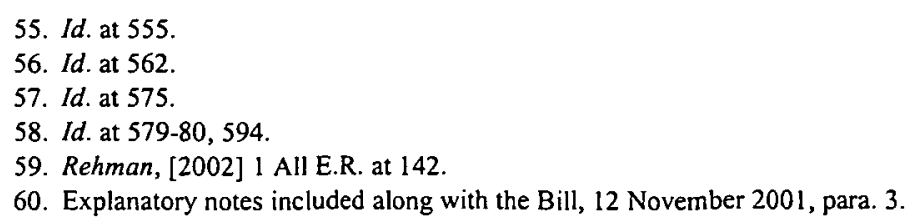


communications data, bribery and corruption on an international dimension, and a number of miscellaneous matters.

The scale of the problems is set out in the Report of the Defence Committee of the House of Commons, ${ }^{61}$ which urges that the global campaign against terrorism should be pursued relentlessly. It includes a history of al Qaeda, an endorsement of the actions of the Prime Minister and the Leader of the Opposition in demonstrating strong support for the United States, an examination of weapons of mass destruction, and a recognition of the defense policy consequences of the events of September 11 th. The Defence Committee does not ignore the humanitarian considerations involved, and another committee of the House of Commons-the Foreign Affairs Committee-has stressed that human rights are central to the Government's response to terrorism, and that the actions of our allies in the international coalition against terrorism should also be subject to scrutiny. ${ }^{62}$

Moreover, while recognizing the work of committees of the House of Commons, and while bearing in mind Lord Hoffmann's view on the involvement of elected representatives, it has to be recognized that the role of Parliament itself is severely reduced in times of crisis such as war or the struggle against terrorism. In the United Kingdom a declaration of war is made under the royal prerogative, now vested in the Government of the day, and it was pointed out in 1996 that - even in the absence of a formal declaration- - on three occasions since 1956 "the Cabinet has committed large military forces to armed conflicts. In none of those cases was Parliament consulted formally before the decision was made to send forces overseas. The Suez canal, the Falkland Islands, and the Gulf all received British armed forces on ministerial direction under the prerogative power to dispose these forces as the Crown thinks fit." ${ }^{363}$ The British involvement in Afghanistan in 2001 and 2002 followed on British involvement in the former Yugoslavia, and further intervention is currently discussed widely.

Such decisions taken by the Government are doubtless based on assessments of what the public would wish or tolerate, and to that extent there is democratic legitimacy. Once a particular intervention is under way, the Government, at least initially, will receive patriotic support from a wide spectrum of publicized opinion. The secondary role of the legislature in the

61. THE THREAT FROM TERRORISM, supra note 43.

62. FOREIGN AFFAIRS COMMITTEE, FIFTH REPORT, 2001, H.C. 589.

63. RODNEY BRAZIER, MINISTERS OF THE CROWN 21 1-12 (1997). 
first initiatives can be corrected if normal channels of accountability emerge, but there are built-in perils for democracy when debate is curtailed, information is restricted, and parliamentary sanction is avoided. With the role of the courts already curtailed in matters of national security, the role of the executive becomes ever larger, and, in the light of globalization, the judges may have to reconsider their long established deference. Incorporation of the European Convention is important, but, well before the Human Rights Act of 1998, there were occasional judicial rumblings. Looking at detention authorized under wartime regulations, Lord Atkin in 1941 claimed in a dissent that "amid the clash of arms the laws are not silent" and protested against a "strained construction" put upon the words of the relevant regulation "with the effect of giving an uncontrolled power of imprisonment to the Minister." ${ }^{, 64}$ In a 1962 House of Lords case, to which Lord Hoffmann referred approvingly in the Rehman decision in 2001, in the context of a challenge in criminal proceedings to the possession of nuclear weapons, Lord Devlin - who did not dissentnevertheless had reservations: men can exaggerate the extent of their interests, he suggested, "and so can the Crown." It was the duty of the courts "to be alert now-they have always been to prevent abuse of the prerogative." G5 Given the capacity of the government to sidestep Parliament in matters of national security, the courts would do well to keep their powder dry.

\section{GENERAL CONSIDERATIONS}

This digression on the global implications of international terrorism is perhaps justified because of events since September 11th. Globalization has many facets, of course, and these have been closely examined by Professor Aman in several publications since his monograph on Administrative Law in a Global Era in $1992 .{ }^{66}$ Not surprisingly, he views the new demands, especially in administrative law, from an American perspective. In the United States there is no equivalent of membership in the European Union or adherence to the European Convention, or of membership in the Commonwealth, all of which add a significant measure of globalization to the public law of the United Kingdom. On the other hand, the United States shares the global concerns associated with international terrorism, concerns which have already affected

64. Liversidge, [1942] A.C. at 244.

65. Chandler v. Director of Pub. Prosecutions, [1964] A.C. 763, 811 (H.L.) (appeal taken from Ct. Crim. App.).

66. Alfred C. Aman, JR., AdMINistrative law in a Global ERA (1992). 
the stance of the British courts. In addition, American observers, like British observers, will wish to monitor the democratic problems created by terrorism.

Likewise, the global economic issues have to be faced by both countries, though those are qualified by Britain's European connections. Many of them raise issues of international law, as do many of the issues of international terrorism; it is evident, as we have seen, that international lawyers are today obliged to address questions of democratic governance. Global environmental issues are more and more recognized at international conferences and in legal decisions, and it is revealing that of the three volumes of the International Environmental Law Reports ${ }^{67}$ published so far by Cambridge University Press, one volume is on Trade and Environment ${ }^{68}$ and another is on Human Rights and Environment. ${ }^{69}$ These illustrate the complexity of an international environmental law which is, of course, complementary to international economic law and its consequences. ${ }^{70}$

Professor Aman has argued that the range of administrative law has changed, in part because of the global issues which obtrude more and more, and in part because of developments such as privatization, deregulation, and devolution. There have been parallel developments in the United Kingdom: in 1994, for instance, Parliament passed the Deregulation and Contracting Out Act, which aimed in part to ease the regulatory control of trade, business, and the professions, and also to establish a mechanism for the delegation to private contractors of certain ministerial and official powers. ${ }^{71}$ In addition, virtually all the former nationalized industries have been privatized in the past two decades, but often with a regulatory mechanism designed to ensure, for example, that privatized public utilities provide a service "which is available to all, is not arbitrarily denied or restricted, and is not over-priced." J2 Judicial review of the independent regulators is one of the new areas of administrative law, ${ }^{73}$ and it is noteworthy that the actions of the regulators attract considerable attention in the media. The tentative nature of judicial review in these new areas of activity should not, however, obscure the tentativeness of judicial review in other, more familiar areas, such as the royal prerogative and secondary or subordinate

67. INTERNATIONAL ENVIRONMENTAL LAW REPORTS (Cairo A.R. Robb ed., 1999) [hereinafter IELR].

68. 2 IELR, supra note 67.

69. 3 IELR, supra note 67.

70. See generally Thomas C. Fischer, The United States, the European UNion and the "GlobalizATION" OF WORLD TRADE: ALLIES OR ADVERSARIES? (2000).

71. See WADE \& FORSYTH, supra note 26 , at $844-45,50-51$.

72. Id. at 173 .

73. Id at at $75-77$. 
legislation. ${ }^{74}$ Nor should it obscure the fact that the control of administrative power, on a national and global basis and with reference to privatized or contracted-out functions as well as to more familiar subject matter, has to be exercised in a variety of ways, of which judicial review is only one. Nevertheless, the courts in the United Kingdom have shown a capacity to adjust and adapt in constitutional and administrative law alike, and, building on foundations laid in the last thirty years, are likely to maintain that impetus in facing the varied challenges of globalization and governance.

74. On secondary legislation, see Sir David Williams, Subordinate Legislation and Judicial Control, 8 PUB. L. REV. 77-87 (1997). 